ago a Medical Practices Advisory Committee was set up as a department of the Association in charge of one of the Assistant Secretaries. The function of this Bureau is to maintain an information service about openings in the various fields of medical practice; to introduce partners, assistants, and locumtenents ; and to advise on all individual and personal problems associated with entry into and conduct of medical practice. Inquiries should be addressed to the medical director of the Bureau either at the head office of the Association in Tavistock Square, London, W.C.1, or at the branch offices at 33, Cross Street, Manchester, 2, and 7, Drumsheugh Gardens, Edinburgh.

The principal work of the Association is done through a large number of standing and special committees. Two of these are what are known as autonomous bodies within their own field, but they are nevertheless Association committees and report to the Council. One of them is the General Medical Services Committee, representing those engaged in general practice within the National Health Service. It is the executive of the Conference of Local Medical Committees, the bodies representing practitioners in each area and recognized as such by the Minister under the Act. It was this committee which carried out the immense work leading to the arbitration and the Danckwerts award, and certain of its members formed part. of the Working Party on the distribution scheme. The other autonomous body is the Central Consultants and Specialists Committee, which deals with all matters affecting those engaged in consulting and specialist practice. Its representatives, together with representatives of the Royal Colleges, form the Joint Committee.

Other Association committees are concerned with public health, occupational health, private practice, medical ethics, and medical charities. One committee is working out an amended structure of the National Health Service Act, and has presented an interim report. A public relations service is maintained which seeks to ensure that matters affecting the profession are properly presented in the Press. In the field of science the Association offers a number of annual prizes and research scholarships. It also publishes many special journals and, in addition, from time to time, valuable reports of special committees dealing with subjects of medical, medico-legal, and medico-sociological interest.

\section{Society of Medical Officers of Health}

The Society of Medical Officers of Health (Tavistock House South, Tavistock Square, London, W.C.1) is a body of medical officers engaged in public health work in all its branches. It publishes an official organ, entitled Public Health. There is reciprocal representation on the Association's Public Health Committee and the Society's Council, and the Public Health Committee acts in conformity with an agreement with the Society of Medical Officers of Health under which medico-political activities in this field are undertaken by the Association.

\section{Medical Women's Federation}

The Medical Women's Federation (Tavistock House North, Tavistock Square, London, W.C.1) also works closely with the Association, and is represented as such by the one woman member on the General Medical Services Committee. The Federation is the only professional organization consisting solely of medical women, and is thus in a position to represent the interests of women doctors and to deal with problems affecting them as a minority in the profession. It also considers and investigates medical matters of special concern to women doctors. The Federation has active local associations all over the kingdom, including a large London association, and an association of its overseas members. These associations meet regularly, and the Journal of the Federation is published quarterly for private circulation among its members.

In addition to the bodies named above there are the defence societies, which are the subject of a separate annotation (page 510), the medical benevolent societies (Royal Medical
Benevolent Fund and Epsom College), and the numerous societies headed by the Royal Society of Medicine and the Medical Society of London whose province it is, mainly by papers and discussions and publications, to advance and record the science and art of medicine.

In the students' field the British Medical Students' Association (B.M.A. House, Tavistock Square, London, W.C.1), a lively and enterprising body that publishes a quarterly journal, holds an extended annual meeting, and organizes clinical conferences, should be mentioned.

\section{Preparations and Appliances}

\section{LIGHT-WEIGHT VAGINAL RETRACTOR}

Dr. K. Vernon Bailey, Consultant Gynaecologist, St. Mary's Hospitals for Women and Children, Manchester, writes: I have always regarded the heavily weighted Auvard retractor as used for vaginal operations as an instrument to be avoided if possible. A retractor of this type exerts its effect by the heavy drag of its weight on the perineum in combination with its relatively large and wide blade. I have often noticed the severe bruising of the perine a 1 region which follows its use in such opera$\mathrm{t}$ i o n s as colporrhaphy or vaginal hysterectomy, and, incidentally, when used in these operations its very weight causes it to fall out altogether when the perineum is deficient or a marked rectocele is present. I have also considered the curved Sims type of retractor to be inadequate for these cases, as the shape is not conducive

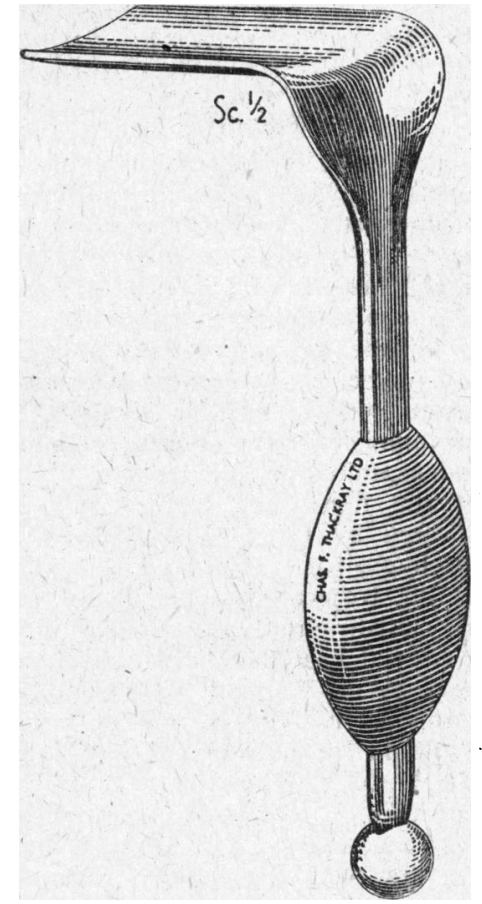

to stability during the operation and the upcurve of the blade interferes with the natural fall of the lateral vaginal walls.

Some two years ago, therefore, I got Messrs. Chas. F. Thackray Ltd. to make a modified light-weight vaginal retractor (see illustration) which $I$ have used ever since with complete satisfaction. The blade is 3 in. $(7.6 \mathrm{~cm}$.) long and $1 \frac{1}{2}$ in. $\left(3.8 \mathrm{~cm}\right.$.) wide at its proximal end, tapering to $1 \frac{3}{8}$ in. $(3.5 \mathrm{~cm}$.) wide, with a slight upward concavity at its distal end. The handle ends in a small knob, and is 7 in. $(17.8 \mathrm{~cm}$.) long. The weight is flattened antero-posteriorly and is minimal to the requirements of stability when the retractor is in position. Owing to its light weight there is no undue drag on the tissues of the perineum or vaginal walls, and consequently colporrhaphy can be carried out more satisfactorily on tissues not unduly stretched. Any tendency for this retractor to fall out during operation can be overcome by the use of a towel clip which includes the perineal sheet and the neck of the instrument just above the weight. The flat nature of the weight allows this retractor to fit closely to the perineum.

I feel that experienced gynaecologists who prefer to traumatize the tissues as little as possible might be interested enough to give this retractor a trial. 